\title{
TINJAUAN HUKUM KEADAAN MEMAKSA(FORCE MAJEURE) DALAM PELAKSANAAN KONTRAK BISNIS PADA MASA PANDEMI COVID-19
}

\author{
Besty Habeahan', Sena Rusiana Siallagan² \\ ${ }^{1,2}$ Program Studi Ilmu Hukum \\ Universitas HKBP Nommensen, Medan-Sumatera Utara-Indonesia \\ e-mail: bestyhabeahan@uhn.ac.id
}

\begin{abstract}
The Legal Review of Force Majeure in the implementation of business contracts during the covid19 pandemic objectives of knowing whether covid 19 pandemic defined by the government as a national disaster which can be classified as a force majeure in the implementation of business contract and to find out how to solve the law against default in the implementation of business contract during the covid 19 as a national disaster. The library research, namely the research conducted in the library where the data is obtained from available data by reading and studying books such as laws of regulation, Scientific works, dictionaries and so on. Based on the method used, the result of this study indicate that force majeure is relative, so the cases that occur must be studied first, because not all the parties get loss but some of them get profit, for the implementation of achievement can be done by considering great effort and sacrifice. Relative Force Majeure is exemption from lost and interest costs, but not for cancelation of agreement. A right solution to solve from dispute is by negotiating with the parties, because the covid 19 pandemic it's self is a new event.
\end{abstract}

\section{Keywords:Force Majeure, Business, Contract}

\begin{abstract}
Abstrak
Penelitian terhadap Tinjauan Hukum Keadaan Memaksa (Force Majeure) Dalam Pelaksanaan Kontrak Bisnis Pada Masa Pandemi Covid-19 bertujuan untuk mengetahui apakah masa pandemi Covid-19 yang ditetapkan pemerintah sebagai bencana nasional dapat digolongkan sebagai keadaan memaksa (Force Majeure) dalam pelaksanaan kontrak bisnis pada masa pandemi covid-19 sebagai bencana nasional. Penelitian Kepustakaan (Library Research) yaitu penelitian yang dilakukan di perpustakaan, dimana data diperoleh dari data yang tersedia dengan cara membaca, mempelajari buku-buku, peraturan perundang-undangan, majalah, karya ilmiah, kamus hukum, dan lain sebagainya. Berdasarkan metode yang digunakan, hasil penelitian ini menunjukkan bahwa keadaan memaksa yang bersifat relatif dimana harus dikaji terlebih dahulu kasus-kasus yang terjadi, karena tidak semua pihak memperoleh kerugian melainkan ada beberapa pihak yang mendapat keuntungan, untuk pelaksanaan prestasi, juga dapat dilakukan mempertimbangkan usaha dan pengorbanan yang besar. Force Majeure yang bersifat relatif adalah pembebasan terhadap biaya, rugi dan bunga namun tidak sampai pada batalnya perjanjian. Penyelesaian sengketa diluar pengadilan yang elegan ialah dengan cara
\end{abstract}


http://ejournal.uhn.ac.id/index.php/opinion

bernegosiasi dengan para pihak, karena pandemi covid-19 itu sendiri merupakan hal yang baru.

\section{Kata kunci: Keadaan Memaksa, Bisnis, Kontrak}

\section{A. Pendahuluan}

Manusia merupakan makhluk sosial yang dimana mereka hidup dengan membutuhkan orang lain. Demi memenuhi kebutuhannya manusia juga harus melakukan pekerjaan, dalam hal ini seluruh aktivitas yang dilakukan manusia dalam rangka memenuhi kebutuhannya tersebut sangat berhubungan dengan orang lain dalam memenuhi kesejahteraan hidupnya. ${ }^{1}$ CoronaVirus-19 atau yang kita kenal COVID-19 merupakan Virus Corona ialah virus yang menyerang sistem pernapasan. Penyakit karena infeksi virus ini disebut COVID-19. Virus Corona bisa menyebabkan gangguan ringan pada sistem pernapasan, infeksi paru-paru yang berat, hingga kematian, virus ini melanda Negara Republik Indonesia pada Desember 2019 silam.

Seiring bertambahnya kasus, Joko Widodo menambahkan status darurat pada Penetapan Bencana Non Alam penyebaran covid-19 dalam Keppres 20 Tahun 2021 tentang Penetapan Bencana Non Alam Penyebaran Corona Virus Disease 2019 (COVID-19) Sebagai Bencana Nasional mengacu Undang-Undang Nomor 24 Tahun 2007 mengenai Penanggulangan Bencana, Penyebaran Covid-19 berdampak luar biasa bagi seluruh lini kehidupan. ${ }^{2}$

Dalam Keppres No. 12 Tahun 202 tentang Penetapan Bencana Non Alam Penyebaran Corona Virus Discase 2019 (COVID-19) sebagai Bencana Nasional ditegaskan bahwa penetapan status darurat nasional karena bertambahnya selalu jumlah korban dan kerugian harta benda, meliputi lingkup wilayah yang terdampak bencana, dan timbulnya keterkaitan sosial, politik dan ekonomi yang sangat luas walaupun jumlah korban terbesar masih terdampak di daerah kota tetapi wabah virus ini menyebar juga ke seluruh penjuru bumi. Pandemi ini sangat mempengaruhi perekonomian serta kestabilan suatu negara. Salah satu langkah yang diambil pemerintah ialah pemberlakuan Penetapan Sosial Berskala Besar (PSBB). Di sisi lain pemberlakuan PSBB ini menimbulkan penurunan aktivitas ekonomi pada kehidupan di masyarakat. Akibat pemberlakukan PSBB ini tempat wisata, mall, pendidikan, perusahaan-perusahaan serta tempat penyedia makanan mengalami penutupan.

Adanya penetapan dalam Keppres Nomor 12 Tahun 2020 COVID-19 tentang Penetapan Bencana Non Alam Penyebaran Corona Virus Disease (COVID-19) sebagai Bencana Nasional menegaskan bahwa pandemi sebagai darurat bencana. Selain itu Darurat Kesehatan Masyarakat juga ditetapkan darurat bencana lain pada masa

\footnotetext{
${ }^{1}$ Ayza Bustamar, Hukum Pajak Indonesia, Kencana, Depok, hlm. 2.

${ }^{2}$ Mochamad Januar Rizki, "Alasan Force Majeure yang Berimplikasi PHK Karyawan", (https://www.hukumonline.come/berita/baca/lt5e957e37dzefo/alasan-forcemajeureyangberimplikasiphkkaryawan), diakses pada tanggal 24 Mei 2021, pada pukul 20:42.

Tinjauan Hukum Keadaan Memaksa(Force Majeure) Dalam Pelaksanaan Kontrak Bisnis Pada 
pandemi ini yaitu Darurat Sipil, Darurat Militer. Darurat Kesehatan Masyarakat diatur dalam Undang-Undang No. 6 Tahun 2018 tentang Kekarantinaan. ${ }^{3}$

Klarifikasi Mahfud MD mengenai Keppres 12 Tahun 2020 tentang Penetapan Bencana non Alam Penyebaran Virus Corona Desease 2019 (COVID-19) sebagai Bencana Nasional pantang dipakai untuk mengajukan pembatalan kontrak, kontrak harus teta dituntaskan sesuai Pasal 1338 KUHPerdata kontrak yang disepakati menjadi Undang-Undang bagi para pembuat kontrak. Pembatalan kontrak tidak diperkenankan tetapi bagi pihak yang terkena efek pandemi diperkenankan bernegosiasi mengenai substansi kontrak yang dirundingkan. Untuk mengurangi dampak penyebaran COVID-19, Kapolri mengeluarkan Maklumat Kepala Kepolisian Negara Republik Indonesia Nomor: Mak/2/III/2020 tentang Kepatuhan Terhadap Kebijakan Pemerintah Dalam Penanganan Penyebaran Virus Corona (COVID-19). Maklumat yang berisi tentang larangan untuk mengadakan kegiatan yang menimbulkan perkumpulan jumlah orang di suatu tempat.

Menurut R. Subekti kontrak adalah "Aktifitas orang memikat diri terhadap orang lain dengan berkomitmen untuk mengerjakan suatu hal dalam konteks bisnis". Kontrak hadir karena adanya persesuaian kehendak atas target yang ingin dicapai, kerjasama tersebut dilakukan guna mempermudah laju transaksi para pihak. ${ }^{4}$ Kehadiran kontrak sangat berkaitan dengan kehadiran prestasi. Jika dikaitkan dengan bisnis, maka suatu kontrak ialah suatu perbuatan hukum yang dimana pihak satu mengikatkan diri dengan pihak lain dimana isi dari perjanjian tersebut menganut nilai komersial.

Beberapa penerapan dari kontrak bisnis dalam kehidupan sehari-hari yaitu: Dalam segi bisnis pada penerbangan ialah adanya penyelesaian kontrak kerja yang dilaksanakan oleh PT. Garuda Indonesia kepada pilotnya, demi meningkatkan sepakterjang yang penting dalam memulihkan performa maskapai, hal ini dilakukan agar semua hak serta kewajiban karyawan dapat terpenuhi dengan baik, memperhatikan kondisi pandemi COVID-19 untuk memenuhi akses penyelamatan menjaga keutuhan kelancaran perusahaan serta mencapai penerimaan penerbangan penumpang yang ideal. ${ }^{5}$

Pada sektor pendidikan dampak daripada COVID-19 ialah pelaksanaan kegiatan belajar mengajar secara daring guna membatasi kontak langsung antar manusia guna mengurangi penyebaran COVID-19 tersebut. Di sektor kegiatan mall pada hypermart, membuat fitur hypermart online dimana pelanggan melakukan pesanan dengan online ataupun pesanan dapat diantarkan ke rumah si pemesan. Banyak restoran wisata di

\footnotetext{
${ }^{3}$ Ibid, hlm. 2.

${ }^{4}$ Muhammad Syaiffudin, Hukum Kontrak Memahami Kontrak Dalam Perspektif Filsafat, Teori, Dogmatik dan Praktik Hukum (Segi Penganyaan Hukum Perikatan), CV. Mandar Maju, 2016, Bandung, hlm. 22.

5 Harry Purnama, Hotel Indonesia Natour akan kerjasama dengan Jaringan Hotel Internasional, https://venuemagz.com/hotel-indonesia-natour-akan-kerja-sama-denganjaringan-hotel-internasional/, diakses tanggal 27 Mei 2021 pukul 21.20.

Tinjauan Hukum Keadaan Memaksa(Force Majeure) Dalam Pelaksanaan Kontrak Bisnis Pada 
Bali yaitu tepatnya di kawasan Pantai Jimbaran, Pantai Kedongangan menutup restoran milik mereka karena tidak adanya wisatawan yang berkunjung ke Bali baik itu wisatawan lokal maupun mancanegara.

Pemerintah juga mengalami dampak dengan harus mengeluarkan berbagai macam kebijakan diantaranya karena kebijakan social distancing yang diterapkan guna mengurangi kontak langsung, pemerintah juga memberi kelonggaran pada pembayaran kredit, pada Usaha Mikro, Kecil, dan Menengah (UMKM), serta adanya subsidi listrik. Bagi aparat penegak hukum imbas yang dialami khususnya dalam penyelesaian sengketa yang dilakukan secara online membuat keterpaksaan untuk beralih dari penanganan sengketa yang cara lama menuju basis teknologi modern pada masa pandemi COVID-19 mampu mengubah cara orang bekerja.

Keadaan memaksa atau force majeure dalam suatu perjanjian diatur dalam KUHPerdata Pasal 1244 dan Pasal 1255. Apabila dilihat lebih lanjut pengaturan mengenai force majeure, dalil tersebut lebih menekankan kepada bagaimana tata cara penggantian biaya, ganti rugi, serta bunga. Namun ketentuan tersebut tetap dapat dijadikan acuan sebagai pengaturan force majeure. ${ }^{6}$ Force Majeure sangat bertalian konsekuensi ganti rugi atas hadirnya kontrak, karena membawa konsekuensi hukum bukan saja hilangnya atau tertundanya kewajiban-kewajiban untuk melaksanakan prestasi yang dari suatu kontrak, melainkan juga suatu force majeure dapat juga memerdekakan para pihak pada ganti rugi akibat tertahannya pelunasan prestasi kontrak. $^{7}$

Pihak debitor yang dapat membuktikan sedang melarat akibat force majeure dalam realisasi prestasi maka dapat mengajukan permohonan negosiasi untuk mendapat penundaan pemenuhan prestasi terhadap kreditor. Tapi setelah pengajuan negosiasi untuk keringanan pada masa force majeure setiap kreditor menuntut prestasinya agar segera dilunasi. ${ }^{8}$ Seiring bertambahnya waktu dan perkembangan dalam dunia usaha, banyak sekali kasus yang terjadi menyangkut kontrak bisnis didalam perputaran dunia usaha terutama pada masa pandemi COVID-19 yang melanda negara Indonesia saat ini.

\section{B. Metode Penelitian}

Pengumpulan data yang digunakan dalam penelitian ini adalah metode penelitian kepustakaan (library research). Data tersebut diperoleh dari lliteratur, peraturan perundang-undangan, artinya yang sudah baku sehingga data yang ada

\footnotetext{
${ }^{6}$ Mochamad Januar Rizki, "Penjelasan Mahfud MD soal Force Majeure Akibat Pandemi Corona", https://www.hukumonline.com/berita/baca/lt5eanca6a5956/penjelasan-prof-mahfud soal-i-force-majeure-i-akibatpandemi-corona?page-3, hlm. 3, diakses tanggal 13 Juni 2021 pukul 23:25.

${ }^{7}$ Desi Syamsiah, “Penyelesaian Perjanjian Hutang Piutang Sebagai Akibat Force Majeure karena Pandemi COVID-19", Legal Standing, Vol. 4 No. 1, Maret 2020, hlm. 331.

${ }^{8}$ Sufiarina dan Sri Wahyuni, "Force Majeure Dan Notoir Feiten Atas Kebijakan PSBB COVID-19", Jurnal Hukum Sasana, Volume 6 Nomor 1, Juni 2020, hlm. 11.

Tinjauan Hukum Keadaan Memaksa(Force Majeure) Dalam Pelaksanaan Kontrak Bisnis Pada 
dilihat dari hukum yang sudah berkekuatan tetap. Analisis data yang dipakai adalah metode analisis normatif yuridis. Data tersebut dianalisis menurut hukum dan peraturan perundang-undangan yang ada serta berlaku saat ini.

\section{Pembahasan}

\section{Masa Pandemi Covid-19 Yang Ditetapkan Pemerintah Sebagai Bencana Nasional Dapat Digolongkan Sebagai Keadaan Memaksa (Force Majure) Dalam Pelaksanaan Kontrak Bisnis pada Masa Pandemi COVID-19}

Sejak Munculnya Pandemi Covid-19 di Indonesia Sangat berdampak pada Tingginya Kenaikan Jumlah Korban dan kerugian harta benda , cakupan wilayah yang semakin meluas akibat bencana Covid-19 ,serta implikasinya pada aspek sosial masyarakat. Demikian juga pada pelaksanaan Kontrak bisnis, Para pihak tidak mampuh Memenuhi kewajibannya diakibatkan keadaan yang tidak memadai hingga tidak terlaksananya prestasi, dikarenakan Pandemi Covid-19 yang semakin meluas.

Oleh sebab itu Pemerintah berupaya mengeluarkan kebijakan-kebijakan hukum, dengan mengeluarkan peraturan-peraturan untuk menanggapi masalah Covid-19 yang semakin mengancam kehidupan masyarakat, baik itu juga mengenai pelaksanaan kegiatan perekonomian. Adapun peraturan-peraturan yang dikeluarkan oleh pemerintah yaitu Keppres Nomor 11 Tahun 2020 tentang Penetapan Kedaruratan Kesehatan Masyarakat Covid-19 ,Keppres No 12 Tahun 2020 Tentang penetapan Bencana Non Alam Penyebaran Covid-19,PP Nomor 21 Tahun 2020 Tentang Pembatasan Sosial Berskala Besar, Undang - Undang No. 2 Tahun 2020 tentang Kebijakan Keuangan Negara dan Stabilitas Sistem Keuangan Negara untuk Penanganan Pandemi COVID-19 dan/atau dalam Rangka Menghadapi Ancaman yang Membahayakan Perekonomian Nasional dan/atau Stabilitas Sistem Keuangan, Peraturan Menteri Kesehatan (Permenkes) No. 9 Tahun 2020 Tentang Pedoman Pembatasan Sosial Berskala Besar Dalam Rangka Percepatan Penanganan COVID-19, Maklumat Kepala Kepolisian Negara Republik Indonesia Nomor: Mak/2/III/2020 Tentang Kepatuhan Terhadap Kebijakan Pemerintah Dalam Penanganan Penyebaran COVID-19.

Pemberlakuan Keppres Nomor 11 Tahun 2020 dan Keppres Nomor 12 Tahun 2020 berimplikasi bahwa keadaan kedaruratan kesehatan masyarakat bersifat mengikat secara umum. Hal tersebut secara signifikan mempengaruhi berjalannya sebuah prestasi dalam sebuah kontrak. Dimana jenis kontrak yang paling terdampak oleh pemberlakuan PP Nomor 21 Tahun 2020, Keppres Nomor 11 Tahun 2020, dan Keppres Nomor 12 Tahun 2020 adalah kontrak yang mengatur pelaksanaan prestasi yang diwujudkan melalui kegiatan melakukan sesuatu atau kegiatan memberikan sesuatu yang dilakukan secara langsung dan berkelanjutan seperti pada kegiatan pemborongan, kegiatan ekspedisi, atau kegiatan sejenis lainnya. 
Pelaksanaan prestasi dalam kontrak yang berhubungan dengan hal ikhwal kegiatan diatas semakin terdampak dengan pemberlakuan PP Nomor 21 Tahun 2020. Dimana Pasal 4 ayat (1) PP Nomor 21 Tahun 2020 menerangkan bahwa pembatasan sosial berskala besar setidaknya meliputi peliburan sekolah dan tempat kerja, pembatasan kegiatan keagamaan, dan/atau pembatasan kegiatan di tempat atau fasilitas umum. Merujuk pada pembatasan kegiatan di tempat atau fasilitas umum tersebut, terdapat implikasi bahwa pelaksanaan kontrak yang berkarakteristik sebagaimana dimaksudkan diatas dimungkinkan untuk tidak dapat berjalan sebagaimana yang telah disepakati oleh para pihak sebelumnya.

Merujuk pada substansi KUHPerdata secara komprehensif maka dapat dikemukakan bahwa wanprestasi sendiri dapat terdiri dari dua jenis klasifikasi. Klasifikasi wanprestasi yang pertama adalah wanprestasi yang dikehendaki oleh pihak kreditur. Mengenai klasifikasi wanprestasi ini setidaknya harus memenuhi dua unsur di dalamnya. Unsur pertama adalah unsur itikad buruk. Unsur itikad buruk yang dimaksudkan adalah apabila pihak kreditur secara sadar bahwa tindakannya dalam pelaksanaan prestasi yang dibebankan kepadanya berpotensi merugikan kepentingan debitur, Dimana meskipun pihak kreditur mempunyai kesadaran tersebut, pihak kreditur tidak melakukan upaya preventif terhadap penerbitan kerugian kepada pihak debitur akibat dari tindakannya.

Selain unsur itikad buruk, unsur yang kedua adalah terdapatnya unsur penipuan yang terjadi dalam kurun waktu pelaksanaan kontrak. Hal ini untuk membedakan konstruksi unsur penipuan yang dimaksudkan oleh Pasal 1328 KUHPerdata. Ketentuan Pasal 1328 KUHPerdata menerangkan bahwa penipuan merupakan alasan untuk membatalkan persetujuan dimana penipuan tersebut menjadi dasar untuk menegakkan persetujuan terkait. ${ }^{9}$ Ketentuan Pasal 1328 KUHPerdata tersebut dapat dipahami bahwa penipuan dapat menjadi alasan untuk dimintakannya pembatalan sebuah persetujuan diantara para pihak apabila unsur penipuan tersebut telah terang dilakukan pada saat fase kontraktual. Hal ini sekaligus untuk menegaskan bahwa apabila unsur penipuan tersebut terjadi pada kurun pelaksanaan prestasi dalam kontrak tersebut maka tidaklah tepat untuk mengacu kepada ketentuan Pasal 1328 KUHPerdata. Dimana ketentuan Pasal 1247 KUHPerdata mengemukakan bahwa penggantian biaya, kerugian, dan bunga sebagai bentuk kerugian yang ditanggung pihak kreditur akibat unsur penipuan yang dilakukan pihak debitur tetap dapat dimintakan pertanggungjawabannya oleh pihak kreditur kepada pihak debitur tanpa mengakibatkan batalnya kontrak yang telah disepakati. ${ }^{10}$

Adapun mengenai Kontrak bisnis dan pelaksanaannya diatur dalam KUHPerdata. Pasal 1244 KUHPerdata, mengatur: "Debitur harus dihukum untuk mengganti biaya, kerugian dan bunga bila ia tak dapat membuktikan bahwa tidak dilaksanakannya

\footnotetext{
${ }^{9}$ Pasal 1328 Kitab Undang-Undang Hukum Perdata.

${ }^{10}$ Pasal 1248 Kitab Undang-Undang Hukum Perdata. 
perikatan itu atau tidak tepatnya waktu dalam melaksanakan perikatan itu disebabkan oleh sesuatu hal yang tak terduga, yang tak dapat dipertanggungkan kepadanya walaupun tidak ada itikad buruk kepadanya." Selanjutnya, Pasal 1245 KUHPerdata, mengatur: "Tidak ada penggantian biaya, kerugian, dan bunga, bila karena keadaan memaksa atau karena hal yang terjadi secara kebetulan, debitur terhalang untuk memberikan atau berbuat sesuatu yang diwajibkan, atau melakukan suatu perbuatan yang terlarang baginya."

Lathifah Hanim dan MS. Noorman, menulis bahwa pengaruh menunda atau menyebabkan pelaksanaan kewajiban suatu pihak dalam perjanjian tersebut tidak mungkin dan sesudah timbul pihak tersebut tidak dapat menghindari atau mengatasi kejadian tersebut. ${ }^{11}$ Force majeure atau keadaan memaksa merupakan pembelaan debitur untuk memberikan indikasi bahwa tidak terlaksananya prestasi sebagaimana diperjanjikan karena adanya hal-hal yang sama sekali tidak dapat diduga dan para pihak tidak dapat bertindak sesuatu terhadap keadaan atau peristiwa yang timbul diluar dugaan tadi. Oleh karena itu, force majeure merupakan suatu alasan yang dibenarkan oleh hukum untuk membebaskan debitur dari kewajiban membayar ganti rugi atas dasar wanprestasi yang dikemukakan oleh pihak kreditur. ${ }^{12}$

Hukum kontrak/perjanjian, peristiwa dikatakan force majeure, apabila terpenuhi tiga syarat, yaitu:

1. Para pihak tidak menduga sebelumnya peristiwa yang menyebabkan terjadinya force majeure,

2. Peristiwa tersebut terjadi di luar kesalahan para pihak yang menyebabkan terjadinya force majeure, dan

3. Tidak adanya itikad buruk para pihak. ${ }^{13}$

Ketentuan dalam Pasal 1244-1245 KUHPerdata menentukan bahwa keadaan memaksa bisa menghilangkan unsur wanprestasi dalam perjanjian, selama keadaan memaksa tersebut benar-benar terjadi dan menghalangi salah satu pihak untuk melakukan kewajibannya. Tidak ada ketentuan bahwa force majeure harus diatur dalam perjanjian untuk bisa dijadikan legalitas jika terjadi kejadian yang memaksa. Jadi pemasukan force majeure dalam kontrak/perjanjian hanya untuk menguatkan saja, akan tetapi bukan berarti kemudian force majeure harus diperjanjikan agar bisa dijadikan alasan untuk tidak perlu melakukan ganti rugi.

Ketentuan force majeure, baik diletakkan dalam perjanjian maupun tidak, pada prinsipnya tetap bisa dijadikan landasan untuk meniadakan kewajiban ganti rugi,

\footnotetext{
${ }^{11}$ Lathifah Hanim and MS. Noorman, Penyelesaian Perjanjian Kredit Bank Sebagai Akibatforce Majeure Karena Gempa Di Yogyakarta, Jurnal Pembaharuan Hukum 3, No. 2 (2016): 161-171, hlm. 162

${ }^{12}$ Subekti, Hukum Perjanjian, Jakarta: Intermasa, 2007, hlm. 55.

${ }^{13}$ Rifqi Hidayat and Parman Komarudin, Tinjauan Hukum Kontrak Syariah TerhadapKetentuan Force Majeure Dalam Hukum Perdata, Syariah Jurnal Hukum Dan Pemikiran 17, No. 1 (2018): 32-46, hlm. 37
}

Tinjauan Hukum Keadaan Memaksa(Force Majeure) Dalam Pelaksanaan Kontrak Bisnis Pada 
selama force majeure tersebut benar-benar terjadi. ${ }^{14}$ Mengenai kemungkinan pelaksanaan prestasi dalam perjanjian, ada dua klasifikasi force majeure, yaitu:

a) Force majeure relatif, yaitu force majeure ini memberikan penekanan bahwa pemenuhan prestasi secara normal tidak dapat dilakukan, masih mungkin dilakukan apabila dipaksakan. Seperti perjanjian ekspor-impor barang, setelah perjanjian dibuat terdapat larangan impor atas barang tersebut;

b) Force majeure absolut, yaitu force majeure absolut apabila sampai kapanpun suatu prestasi yang terbit dari kontrak tidak dapat dilakukan lagi. Misalnya jika barang yang merupakan objek dari kontrak tersebut telah musnah akibat terbakar diluar kesalahan debitur. ${ }^{15}$

Dikaitkan dengan mewabahnya Covid-19 membuat seluruh aktivitas kegiatan masyarakat, termasuk aktivitas bisnis dari suatu perusahan menjadi terbatas. Terkendalanya operasional akan berdampak terhadap pemasukan yang diperoleh perusahaan yang berimplikasi pada kesulitan untuk memenuhi kewajibannya termasuk hak-hak pekerja/buruhnya. Berdasar pada Pasal 1 ayat (3) Undang-Undang Nomor 24 Tahun 2007 tentang Penanggulangan Bencana, bahwa bencana non-alam adalah bencana yang diakibatkan oleh peristiwa atau rangkaian peristiwa non-alam yang antara lain berupa gagal teknologi, gagal modernisasi, epidemi, dan wabah penyakit. Berdasar pada Undang-Undang Nomor 24 Tahun 2007 tentang Penanggulangan Bencana di atas, bahwa epidemi dan wabah penyakit dapat dikualifikasikan sebagai bencana non-alam karena adanya rangkaian peristiwa nonalam. Hal ini menimbulkan pertanyaan, apakah Covid-19 dikualifikasi sebagai bencana non-alam? Mengacu pada Organisasi Kesehatan Dunia (WHO) yang telah menetapkan bahwa Covid-19 adalah sebuah pandemi. Begitu juga Pemerintah Indonesia melalui Keputusan Presiden Nomor 12 Tahun 2020 tentang Penetapan Covid-19 Sebagai Bencana Nasional.

Pernyataan Mahfud MD yang dikutip Mochamad Januar Rizki, Covid-19 sebagai bencana non-alam tidak dapat langsung dijadikan alasan pembenaran untuk melakukan pembatalan perjanjian dengan alasan force majeure. Keppres 12 Tahun 2020 sebagai dasar untuk membatalkan kontrak-kontrak keperdataan, terutama kontrakkontrak bisnis merupakan kekeliruan. Ada ketentuan bahwa force majeure dapat dijadikan alasan untuk membatalkan kontrak di dalam hukum perjanjian. ${ }^{16}$ Banyaknya anggaran yang telah dikeluarkan untuk menangani pandemi Covid-19, seharusnya dianggap sebagai force majeure khusus. Berbagai peraturan dan standar kontrak belum

\footnotetext{
${ }^{14}$ Husni Thamrin, Landasan Yuridis Gugatan Pembatalan Perjanjian Build Operate Transfer, Jurnal Ilmu Hukum The Juris II, No. 1 (2018): 21-34, hlm. 26.

${ }^{15}$ ibid hlm. 37-38.

${ }^{16}$ Mahfud MD dalam Mochamad Januar Rizki, Penjelasan Prof Mahfud Soal Force Majeure Akibat Pandemi Corona. https://www.hukumonline.com/berita/baca/lt5eanca6a5956/penjelasanprofmahfud-soal-i-force-majeure-i-akibatpandemi-corona?page=2.diakses 11 Juni 2021 Pukul 21:09
}

Tinjauan Hukum Keadaan Memaksa(Force Majeure) Dalam Pelaksanaan Kontrak Bisnis Pada 
memasukkan Covid-19 sebagai peristiwa force majeure pada klausulanya. ${ }^{17}$ Interpretasi dan penerapan klausul force majeure selama pandemi seperti Covid-19, tergantung pada pengadilan dan umumnya pengadilan memeriksa seluruh kontrak. Hal yang sama dilakukan untuk memastikan bagaimana kinerja kontrak dianggap mustahil. Fakta bahwa kewajiban yang seharusnya dikeluarkan oleh suatu pihak telah menjadi berat atau mahal tidak hanya akan menarik penerapan klausul force majeure. Oleh karena itu, penting bahwa pihak yang mencari pemulihan berdasarkan klausul ini, menunjukkan bahwa satu-satunya alasan mengapa gagal untuk menghargai kewajiban adalah karena pandemi Covid-19. ${ }^{18}$

Hal penting yang menjadi syarat pemutusan hubungan kerja perusahaan kepada para pekerja yaitu, perusahaan terbilang mengalami penurunan atau kerugian selama 2 tahun. Sementara, pandemi Covid-19 saat ini belum mencapai atau terbilang 2 tahun. ${ }^{19}$ Adanya pembatasan sosial berskala besar pada masa pandemi Covid-19, membuat pekerja atau karyawan dalam memenuhi kewajibannya tidak dapat dilaksanakan secara optimal. Berbeda halnya jika kontrak yang dibuat berkaitan dengan usaha jasa digital marketing yang masih dapat dikerjakan dengan berbagai upaya lain dan tidak ada hubungan kausal, sekalipun bencana Covid-19 terjadi. Oleh karena itu, force majeure ini perlu dilihat secara kasuistik. Suatu perjanjian secara tegas mengatur adanya pengecualian wabah virus, pandemik, atau tindakan pemerintah sebagai force majeur, maka tidak boleh ada pihak yang mengklaim force majeure karena adanya wabah Covid-19, sehingga pihak-pihak yang terlibat dalam perjanjian harus melakukan kewajibanya berdasarkan perjanjian.

Dengan demikian, sangat jelas bahwa untuk menentukan apakah Covid-19 dapat dijadikan sebagai dasar penerapan force majeure dalam perjanjian/kontrak, maka terlebih dahulu untuk dilihat apakah perjanjian tersebut mengatur mengenai force majeur, dan perlu diketahui apa-apa saja yang termasuk dalam force majeure yang diatur dalam kontrak/perjanjian itu. Jika suatu perjanjian dalam klausulanya tidak mengatur detail tentang perisitiwa alam atau non alam yang termasuk kedalam force majeure maka yang perlu diperhatikan adalah jenis prestasi dari perjanjian tersebut. Contohnya, prestasinya adalah kewajiban membayar utang maka keadaan dari penyebaran Covid-19 bukan dianggap force majeure karena kewajibanya masih bisa dilaksanakan lewat ATM atau mobile banking. Namun, jika prestasinya berupa „melakukan sesuatuee seperti penyanyi yang seharusnya melaksanakan konser, maka penyanyi ini bisa dibebaskan dari kewajibanya. ${ }^{20}$

\footnotetext{
${ }^{17}$ Seng Hansen, Does the COVID-19 Outbreak Constitute a Force Majeure Event? A Pandemic Impact on Construction Contracts,Journal of the Civil Engineering Forum 6, No. 2 May (2020): 201-214, p. 208.

${ }^{18}$ Saurabh Sood, COVID-19 As a Force Majeure in Corporate Transactions, Purakala (UGC Care Journal) 31, No. 34 (April 17, 2020): 17-26, p. 19.

${ }^{19}$ Imas Novita Juaningsih, Analisis Kebijakan PHK Bagi Para Pekerja Pada Masa Pandemi Covid-19 Di Indonesia, Vol. 4, No. 1 (2020): 189-196, hlm. 190. diakses 11 Juni 2021 Pukul 22:40

${ }^{20}$ https://kawanhukum.id/keterkaitan-force-majeure-akibat-covid-19-dalam-kontrakperjanjian/diakses pada tanggal 11 Juni 2021 Pada Pukul 12:20

Tinjauan Hukum Keadaan Memaksa(Force Majeure) Dalam Pelaksanaan Kontrak Bisnis Pada 
Penafsiran bencana Covid-19 sebagai force majeure atas kontrak didasarkan pada asas "clausula rebus sic stantibus (things thus standing)", yang berarti suatu kontrak dapat batal atau para pihak dapat mengakhiri kontrak, apabila terjadi perubahaan fundamental terhadap keadaan-keadaan yang meliputi kontrak tersebut. Oleh karena itu, pembuktian bencana Covid-19 sebagai force majeure atas kontrak akan sangat bergantung pada bencana itu memberikan pengaruh fundamental pelaksanaan kontrak dan klausul-klausulnya. ${ }^{21}$

Meskipun demikian, adanya pandemi Covid-19, ada perusahaan yang tidak dapat beroperasi secara maksimal sehingga patut dimaafkan apabila pihak yang tidak dapat melaksanakan kewajibannya memiliki bukti di pengadilan bahwa Covid-19 merupakan force majeure, dan ada hubungan sebab akibat yang secara langsung antara Covid-19 dengan tidak dipenuhinya kewajiban tersebut. Akan tetapi, sangat sulit untuk menjadikan Covid-19 sebagai dalil klaim force majeure tanpa adanya kebijakan pemerintah, seperti pembatasan perjalanan atau penguncian yang telah menciptakan hambatan untuk operasi bisnis, karena akan sulit untuk menentukan pada titik mana tepatnya Covid-19 dapat dikategorikan sebagai acara force majeure.

Debitur tidak dapat dinyatakan wanprestasi karena tidak terlaksananya kewajiban kontraktual bukan karena kesengajaan maupun kelalain melainkan karena pandemi Covid-19. Pihak yang memiliki kewajiban kontraktual tidak dapat diminta ganti rugi dalam hal terdapat keadaan yang tidak dapat diperkirakan sebelumnya atau di luar kendali yang wajar karena adanya faktor eksternal. Selain itu, perjanjian yang telah dibuat memungkinan untuk dilakukan perubahan/ addendum perjanjian akibat pandemi Covid-19 dengan tujuan para pihak tetap dapat menjalankan kewajiban sebagaimana yang diatur dalam perjanjian yang telah disepakati, dan itu juga harus dilihat dari klausula yang mengaturnya. Hal itu dilakukan agar terwujud asas keseimbangan dan keadilan dalam kontrak.

\section{Penyelesaian Hukum Terhadap Wanprestasi Dalam Pelaksanaan Kontrak Bisnis Pada Masa Pandemi COVID-19 Sebagai Bencana Nasional}

Pada perjanjian yang mengalami force majeur, debitur tidak melaksanakan prestasi atau wanprestasi bukan disebabkan oleh faktor kesengajaan atau kelalaian, melainkan karena adanya keadaan yang terjadi di luar dugaan dan kemampuan debitur. Hal ini mengakibatkan debitur tidak dapat dituntut ganti rugi atau hilangnya hak kreditur atas pemenuhan prestasi pada debitur, dan keadaan memaksa yang mengakibatkan tidak terlaksananya atau terlambatnya pelaksanaan prestasi harus dibuktikan oleh debitur. Terdapat Penyelesaian sengketa yang diatur dalam UndangUndang No. 30 Tahun 1999 tentang Arbitrase dan Alternatif Pilhan Penyelesaian Sengketa). Yaitu lima cara, konsultasi, negosiasi, mediasi, konsiliasi atau penilaian ahli,

\footnotetext{
${ }^{21}$ Ibid.

Tinjauan Hukum Keadaan Memaksa(Force Majeure) Dalam Pelaksanaan Kontrak Bisnis Pada 
yang menurut penulis sebagai landasan yang tepat untuk menyelesaikan sengketa tersebut.

Maka itu, dalam penyelesaian wanprestasi oleh debitur di masa pandemi, Jika terjadi wanprestasi pada pelaksanaan kontrak bisnis pada masa pandemi COVID -19, penyelesaian sengketa diluar pengadilan yang elegan ialah dengan cara bernegosiasi dengan para pihak, karena pandemi COVID -19 itu sendiri merupakan suatu hal yang baru. Dan tidak ada unsur kesengajaan untuk mengakibatkan wanprestasi pada pelaksanaan kontrak bisnis, melainkan karena dampak pandemi Covid-19 yang sangat berpengaruh dengan terhambatnya pelaksanaan kontrak tersebut, sehingga melakukan renegosiasi kontrak adalah cara terbaik untuk menyelesaikan sengketa dimasa pandemi COVID -19 untuk memperoleh output maksimal yaitu winwinsolution bagi para pihak. Apabila upaya renegosiasi belum mencapai hasil yang menguntungkan, maka pihak yang merasa dirugikan dapat mengajukan gugatan ke pengadilan agar Hakim memutuskan putusan terhadap sengketa kontrak bisnis yang hingga tercapai prinsip keadilan dan kemanfaatan bagi para pihak.

\section{D.Kesimpulan}

Adapun yang menjadi kesimpulan dalam penelitian ini adalah :

Masa pandemi COVID-19 dapat dipahami sebagai keadaan memaksa/force majure, yang digolongkan kedalam keadaan memaksa yang bersifat relatif dimana harus dikaji terlebih dahulu kasus-kasus yang terjadi karena tidak semua pihak memperoleh kerugian melainkan ada beberapa pihak yang mendapat keuntungan, untuk pelaksanaan prestasi juga dapat dilakukan mempertimbangkan usaha dan pengorbanan yang besar. force majeure yang bersifat relatif adalah pembebasan terhadap biaya, rugi dan bunga, namun tidak sampai pada batalnya perjanjian, dalam sifat relatif pembebasan hanya bersifat sementara dan selama keadaan force majeure menghalangi debitur melakukan prestasi. Bila keadaan force majeure hilang, maka kreditur dapat menuntut pemenuhan prestasi. Dalam kaitannya dengan Covid-19, dapat dikategorisasikan sebagai force majeure yang bersifat relatif.

Penyelesaian sengketa diluar pengadilan yang elegan ialah dengan cara bernegosiasi dengan para pihak, karena pandemi COVID -19 itu sendiri merupakan suatu hal yang baru. Melakukan renegosiasi kontrak adalah cara terbaik untuk menyelesaikan sengketa dimasa pandemi COVID -19 untuk memperoleh output maksimal yaitu win-win solution bagi para pihak. Apabila upaya renegosiasi belum mencapai hasil yang menguntungkan, maka pihak yang merasa dirugikan dapat mengajukan gugatan ke pengadilan agar Hakim memutuskan putusan terhadap sengketa kontrak bisnis yang sehimgga tercapai prinsip keadilan dan kemanfaatan bagi para pihak.

\section{Daftar Pustaka}

Desi Syamsiah, "Penyelesaian Perjanjian Hutang Piutang Sebagai Akibat Force Majeure karena Pandemi COVID-19", Legal Standing, Vol. 4 No. 1, Maret 2020, hlm. 331.

Sufiarina dan Sri Wahyuni, "Force Majeure Dan Notoir Feiten Atas Kebijakan PSBB COVID-19", Jurnal Hukum Sasana, Volume 6 Nomor 1, Juni 2020, hlm. 11. 
Lathifah Hanim and MS. Noorman, Penyelesaian Perjanjian Kredit Bank Sebagai Akibatforce Majeure Karena Gempa Di Yogyakarta, Jurnal Pembaharuan Hukum 3, No. 2 (2016): 161171, hlm. 162

Rifqi Hidayat and Parman Komarudin, Tinjauan Hukum Kontrak Syariah TerhadapKetentuan Force Majeure Dalam Hukum Perdata, Syariah Jurnal Hukum Dan Pemikiran 17, No. 1 (2018): 32-46, hlm. 37

Husni Thamrin, Landasan Yuridis Gugatan Pembatalan Perjanjian Build Operate Transfer, Jurnal Ilmu Hukum The Juris II, No. 1 (2018): 21-34, hlm. 26

Seng Hansen, Does the COVID-19 Outbreak Constitute a Force Majeure Event? A Pandemic Impact on Construction Contracts,Journal of the Civil Engineering Forum 6, No. 2 May (2020): 201-214, p. 208

Saurabh Sood, COVID-19 As a Force Majeure in Corporate Transactions, Purakala (UGC Care Journal) 31, No. 34 (April 17, 2020): 17-26, p. 19

Imas Novita Juaningsih, Analisis Kebijakan PHK Bagi Para Pekerja Pada Masa Pandemi Covid-19 Di Indonesia, Vol. 4, No. 1 (2020): 189-196, hlm. 190

\section{Peraturan Perundang-undangan}

Pasal 1328 Kitab Undang-Undang Hukum Perdata.

Pasal 1248 Kitab Undang-Undang Hukum Perdata.

Undang-Undang Dasar Negara Republik Indonesia Tahun 1945 .

Undang-Undang Nomor 7 Tahun 2017 tentang Pemilihan Umum.

Undang-Undang Nomor 1 Tahun 2015 tentang Penetapan Peraturan Pemerintah Pengganti Undang-Undang Nomor 1 Tahun 2014 tentang Pemilihan Gubernur, Bupati, dan Walikota

Peraturan Mahkamah Konstitusi Nomor 6 Tahun 2017 tentang Pedoman Beracara dalam Perkara Perselisihan Hasil Pemilihan Gubernur, Bupati, dan Walikota dengan satu pasangan calon.

Peraturan Dewan Kehormatan Penyelenggara Pemilihan Umum Republik Indonesia Nomor 2 Tahun 2017 tentang Kode Etik dan Pedoman Perilaku Penyelenggara Pemilihan Umum.

Peraturan Badan Pengawas Pemilihan Umum (BAWASLU) Nomor 13 tahun 2017 tentang Tata Cara Penanganan Pelanggaran Administrasi Terkait Larangan Memberikan dan/atau Menjanjikan Uang atau Materi Lainnya Yang Dilakukan Secara Terstruktur, Sistematis, dan Masif Dalam Pemilihan Gubernur, Bupati, dan Walikota.

\section{Buku:}

Ayza Bustamar, Hukum Pajak Indonesia, Kencana, 2017, Depok, hlm. 2

Muhammad Syaiffudin, Hukum Kontrak Memahami Kontrak Dalam Perspektif Filsafat, Teori, Dogmatik dan Praktik Hukum (Segi Penganyaan Hukum Perikatan), CV. Mandar Maju, 2016, Bandung, hlm. 22.

Subekti, Hukum Perjanjian, Jakarta: Intermasa, 2007, hlm. 55.

\section{Internet:}

https://www.hukumonline.come/berita/baca/lt5e957e37dzefo/alasan-forcemajeureyang berimplikasiphk-karyawan), diakses pada tanggal 24 Mei 2021, pada pukul 20:42.

https://venuemagz.com/hotel-indonesia-natour-akan-kerja-sama-denganjaringan-hotelinternasional/, diakses tanggal 27 Mei 2021 pukul 21.20. 
Nommensen Journal of Legal Opinion (NJLO)

Jurnal Magister Hukum Program Pascasarjana Universitas HKBP Nommensen

Volumeo2 Nomor 02 Juli 2021 Halaman. 168-18o e-ISSN: 2723-164X p-ISSN: 2722-9858

http://ejournal.uhn.ac.id/index.php/opinion

https://www.hukumonline.com/berita/baca/lt5eanca6a5956/penjelasan-prof-mahfud soal-iforce-majeure-i-akibat-pandemi-corona?page-3, hlm. 3, diakses tanggal 13 Juni 2021 pukul 23:25.

https://www.hukumonline.com/berita/baca/lt5eanca6a5956/penjelasanprofmahfud-soal-iforce-majeure-i-akibat-pandemi-corona?page=2.diakses 11 Juni 2021 Pukul 21:09

https://kawanhukum.id/keterkaitan-force-majeure-akibat-covid-19-dalam-kontrak perjanjian/diakses pada tanggal 11 Juni 2021 Pada Pukul 12:20 